\title{
Growth kinetics of Staphylococcus aureus and background microorganisms in camel milk
}

\author{
Zhaopeng Xie, ${ }^{1}$ Yabo Peng, ${ }^{1}$ Changcheng Li, ${ }^{1}$ Xiaojuan Luo, ${ }^{1}$ Zhaoyi Wei, ${ }^{1}$ Xiaoting Li, ${ }^{1}$ Yukun Yao, \\ Ting Fang, ${ }^{1 *}$ (i) and Lihan Huang ${ }^{2 *}$ \\ ${ }^{1}$ School of Food Science, Fujian Agriculture and Forestry University, Fuzhou 350001, Fujian Province, China \\ ${ }^{2}$ Residue Chemistry and Predictive Microbiology Research Unit, Eastern Regional Research Center, USDA Agricultural Research Service, \\ Wyndmoor, PA 19038
}

\section{ABSTRACT}

Staphylococcus aureus is a common foodborne pathogen that is ubiquitous in nature. Consumption of contaminated foods, such as dairy products, can lead to food poisoning caused by heat-stable staphylococcal toxins that are not easily destroyed during pasteurization. The objective of this study was to investigate the growth kinetics of $S$. aureus and background microorganisms in camel milk stored at different temperatures between 8 and $43^{\circ} \mathrm{C}$ using one-step kinetic analysis to estimate the kinetic parameters from the observed growth curves. The growth of $S$. aureus showed apparent lag, exponential, and stationary phases, whereas no or negligible lag phase was observed for background microorganisms. Data analysis showed that the estimated minimum, optimum, and maximum growth temperatures were $5.9,42.0$, and $49.2^{\circ} \mathrm{C}$ for $S$. aureus, and 3.0, 38.6 , and $49.2^{\circ} \mathrm{C}$ for the background microorganisms, respectively. The estimated optimum specific growth rate was higher for $S$. aureus $\left(1.24 \mathrm{~h}^{-1}\right)$ than for background microorganisms $\left(0.995 \mathrm{~h}^{-1}\right)$. This study found that camel milk may inhibit the growth of $S$. aureus, as it exhibits a lower specific growth rate than that in cow milk or cooked potato. It also has a longer lag phase than that in cow milk at comparable temperature ranges. This unique property is probably related to the presence of some antimicrobial compounds naturally occurring in camel milk. Validation of kinetic parameters and models showed that the root mean square error of prediction was only $0.5 \log \mathrm{cfu} / \mathrm{mL}$ for $S$. aureus and background microorganisms, suggesting that the models are reasonably accurate. These models can be used for conducting risk assessments of S. aureus and

\footnotetext{
Received March 30, 2020.

Accepted July 2, 2020.

*Corresponding authors: fangting930@163.com and lihan.huang@
} usda.gov predicting the general microbiological shelf life of camel milk to prevent foodborne staphylococcal poisoning. Key words: Staphylococcus aureus, growth modeling, predictive microbiology, camel milk

\section{INTRODUCTION}

Staphylococcus aureus is a gram-positive bacterium that is both commensal and pathogenic in animals and humans. It is a major cause of food poisoning (Lee et al., 2014; Mohammadi and Hanifian, 2015). It is typically present on the skin and mucosae of reservoir hosts such as dairy cattle, where it is frequently associated with subclinical mastitis, leading to contamination of raw cow milk and its products (Sağlam et al., 2017). It is also found in meat and meat products, eggs, and other animal-derived foods (Argudín et al., 2010). The optimum growth temperature of $S$. aureus is between 30 and $37^{\circ} \mathrm{C}$. The latency period in human infections is short. Symptoms may become apparent about 2 to 8 $\mathrm{h}$ after eating contaminated food, and include nausea, vomiting, diarrhea, and abdominal cramps. In severe cases, infection can lead to enteritis, sepsis, and other disease complications (Argudín et al., 2010). Many strains of $S$. aureus produce enterotoxins with demonstrated emetic activity. Five major types (A, B, C, D, and $\mathrm{E}$ ) of staphylococcal enterotoxins have been identified. They are responsible for the symptoms of food poisoning associated with this pathogen, although most food poisoning is caused by staphylococcal A enterotoxin (SEA; Carfora et al., 2015). Staphylococcus aureus is generally relatively heat sensitive, but some cells may survive inadequate heating in minimally processed or unprocessed products such as raw milk (Heidinger et al., 2009; Carfora et al., 2015). The staphylococcal enterotoxins, on the other hand, are relatively heat stable and can survive after heat pasteurization. They are basic proteins that are difficult to eliminate even at high temperatures and may survive even after being heated at $121^{\circ} \mathrm{C}$ for $20 \mathrm{~min}$ (Schubert et al., 2018). 
According to the US Centers for Disease Prevention and Control (CDC, 2016), staphylococcal enterotoxin is responsible for $2 \%$ of confirmed or suspected cases of foodborne disease outbreaks in the United States. In Europe, the European Food Safety Agency reported a total of 5,550 food poisoning cases in 2009, affecting almost 49,000 people and causing 46 deaths. Among these, 293 cases were caused by Staphylococcus spp. and bacterial toxins (Schelin et al., 2011). Staphylococcus aureus can be found in bulk tank milk (Oliver et al., 2009). A survey in California showed that $S$. aureus was present in $25.3 \%$ of 51,963 raw milk samples (Heidinger et al., 2009). In 2000, S. aureus-contaminated dairy products resulted in 13,420 cases of food poisoning in Kansai district in Japan (Asao et al., 2003). Because the toxins are heat-stable, it is necessary to control the growth of $S$. aureus in raw milk to prevent staphylococcal poisoning.

Improper storage of raw milk, particularly temperature abuse, may allow S. aureus to grow. Moreover, minimal processing or inadequate pasteurization may not eliminate this microorganism in raw milk, allowing its growth and multiplication in processed raw milk or dairy products (O'Brien et al., 2009). As a result, milk and dairy products are very susceptible to $S$. aureus contamination. To address $S$. aureus contamination in milk and milk products, maximum acceptable limits and microbiological criteria for its presence in dairy products have been established in many countries. For example, France permits up to $10^{3} \mathrm{cfu} / \mathrm{g}$ of $S$. aureus in dairy products (Kérouanton et al., 2007). Canada allows up to $10^{2} \mathrm{cfu} / \mathrm{g}$ in pasteurized milk cheese and up to $10^{3} \mathrm{cfu} / \mathrm{g}$ in raw milk cheese (LeLoir et al., 2003). However, South Korea applies a "zero tolerance" approach to $S$. aureus in dairy products (Lee et al., 2015). With low levels of $S$. aureus allowable in dairy products, it is necessary to prevent temperature abuse to control the formation of enterotoxins.

Camel milk has a high nutritional value and it may be naturally contaminated with pathogenic microorganisms, such as S. aureus and Salmonella spp. (El-Ziney and Al-Turki, 2007; Abera et al., 2016; Elhosseny et al., 2018; Ismaili et al., 2019). Although the composition of camel milk is similar to that of cow milk, it has hypoallergenic properties, containing a high amount of lactoferrin, a ferritin protein that can be easily absorbed and has immune system-enhancing properties (Ibrahim and Khalifa, 2015). Camel milk is also used medicinally in different cultures. Both fresh camel milk and sour camel milk are used to treat certain diseases, including pathological jaundice, bronchial asthma, kala-azar, asthma, edema, and diabetes in India and Russia (Khalesi et al., 2017). In addition, camel milk, like human milk, has low allergenicity because it does not contain $\beta$-lactoglobulin, although it does contain Q-lactalbumin (Khalesi et al., 2017). According to the FAOSTAT database of the United Nations Food and Agriculture Organization, the worldwide production of fresh whole camel milk was 1.8 million tonnes in 2000. Production has been relatively stable since 2008 and was about 3.1 million tonnes in 2018 (FAO, 2020). This reflects a consistent increase in consumer interest and there is considerable potential for further development and application of camel milk by the food industry. Therefore, it is important to study how $S$. aureus grows under different temperature conditions in camel milk to ensure and assess the safety and quality of the product during production, processing, transportation, and storage.

A few predictive models have been reported for describing the growth of $S$. aureus in foods. Fujikawa and Morozumi (2006) used a modified logistic model to describe the growth and toxicity of $S$. aureus in sterilized milk at temperatures between 14 and $36.5^{\circ} \mathrm{C}$. Fujikawa (2010) also used the modified logistic model to describe the growth of $S$. aureus and reported that enterotoxins may increase linearly with time after the number of bacteria reached $6.5 \log \mathrm{cfu} / \mathrm{mL}$, even after the rate of bacterial growth had stabilized, suggesting the need to control the growth of this microorganism to prevent formation of heat-stable enterotoxins.

The objective of this study was to investigate the growth kinetics of $S$. aureus in pasteurized camel milk under different storage temperature conditions and to describe its growth behavior using a primary model and a secondary model using a one-step kinetic analysis method. We anticipated that the results would provide useful information and predictive models for the food industry and food safety regulatory bodies when conducting risk assessments for $S$. aureus contamination of camel milk-based dairy products.

\section{MATERIALS AND METHODS}

\section{Bacterial Strains and Preparation of Bacteria}

Two strains of Staphylococcus aureus, CICC 10786 (type A enterotoxin) and CICC 10787 (type D enterotoxin), were obtained from the culture collection at the China Center of Industrial Culture Collection (CICC, Beijing, China). The working cultures were induced to resist rifampicin by inoculation and successive transfers of each strain into $10 \mathrm{~mL}$ of brain heart infusion broth [Guangdong Huankai Microbiology Technology Co. Ltd. (GHMTC), Guangzhou, China] containing different levels of rifampicin and incubating overnight 
at $37^{\circ} \mathrm{C}$ until they developed resistance to $100 \mathrm{mg} / \mathrm{L}$ of rifampicin. The resulting rifampicin-resistant cultures were transferred to and regularly propagated on tryptic soy agar (TSA) plates (GHMTC) supplemented with $100 \mathrm{mg} / \mathrm{L}$ rifampicin $(\mathbf{T S A} / \mathbf{R})$ and stored at $5^{\circ} \mathrm{C}$ to maintain the cell viability. In a preliminary study, no significant difference in the growth behaviors of natural and rifampicin-resistant strains of $S$. aureus in camel milk was observed. Therefore, the antibiotic-resistant strains of $S$. aureus were used to inoculate camel milk samples. The use of rifampicin-resistant strains permitted easy recovery and enumeration of $S$. aureus cells from inoculated samples that contained background microorganisms.

One day before the start of an experiment, each bacterial strain was picked using an inoculation loop and individually transferred into $10 \mathrm{~mL}$ of brain heart infusion broth and incubated at $37^{\circ} \mathrm{C}$ on an orbital shaker ( $100 \mathrm{rpm})$ for 20 to $22 \mathrm{~h}$. Each overnight bacterial culture was harvested by centrifugation at $2,795 \times g$ for 15 min at $4^{\circ} \mathrm{C}$. The supernatant was discarded and the pellets washed once with $10 \mathrm{~mL}$ of sterile $0.1 \%$ peptone water (Hangzhou Microbial Reagents Co. Ltd., Hangzhou, China). The resulting cultures were then centrifuged at $2,795 \times g$ at $4^{\circ} \mathrm{C}$ for $15 \mathrm{~min}$ and resuspended in $5 \mathrm{~mL}$ of $0.1 \%$ peptone water. Subsequently, a $10-\mathrm{mL}$ cocktail was created by combining equal volumes (5 $\mathrm{mL}$ ) of each strain. The cocktail was then diluted with $0.1 \%$ peptone water to obtain an inoculum containing $10^{5-6} \mathrm{cfu} / \mathrm{mL}$ or 5 to $6 \log \mathrm{cfu} / \mathrm{mL}$ of $S$. aureus. A fresh inoculum of the bacteria was prepared on the day of each experiment.

\section{Sample Preparation and Inoculation}

Camel milk was obtained from Tianshan Pastoral Investment Co. Ltd. (Xinjiang Autonomous Region, China). The samples were divided into small bottles and maintained at $-80^{\circ} \mathrm{C}$. Frozen camel milk was transferred to a refrigerator $\left(\sim 4^{\circ} \mathrm{C}\right)$ to thaw the night before an experiment. A $10-\mathrm{mL}$ sample of the fully thawed milk was then transferred into $16-\mathrm{mL}$ sterile glass test tubes. A total of 15 to 20 test tubes was used for each experimental temperature treatment. The samples were placed in a constant-temperature water bath maintained at $64^{\circ} \mathrm{C}$ for 30 min for pasteurization and then cooled with iced water. After checking that no $S$. aureus was found on Baird-Parker agar (GHMTC) plates after pasteurization, a $0.1-\mathrm{mL}$ aliquot of $S$. aureus was added to a test tube and mixed to achieve an initial concentration of $10^{2-3} \mathrm{cfu} / \mathrm{mL}$ in the camel milk for each treatment. After inoculation, the culture tubes were properly labeled and capped.

\section{Growth Study}

Inoculated camel milk samples were placed in incubators maintained at constant temperatures of $8,12,15$, $20,25,30,33,37,40,43$, and $46^{\circ} \mathrm{C}\left( \pm 0.1^{\circ} \mathrm{C}\right)$. Samples were removed from the incubators at predetermined time intervals according to incubation temperatures. Bacterial growth was examined by enumerating the bacterial cells in each tube. Typically, data from 8 to 15 sampling points of $S$. aureus and background microorganisms were used for the establishment of each growth curve at each incubation temperature. After retrieval from the incubator, the camel milk samples were vortexed, and plated $(0.1 \mathrm{~mL})$ onto TSA and TSA/R plates either directly or after appropriate serial dilutions with PW. Because the TSA/R plates contained rifampicin, only the rifampicin-resistant $S$. aureus could grow on the plates, whereas background microorganisms were effectively suppressed, allowing accurate enumeration of $S$. aureus. The inoculated TSA/R plates were incubated at $37^{\circ} \mathrm{C}$ for 24 to $48 \mathrm{~h}$. The samples were also plated onto regular TSA plates to determine the total plate counts. These TSA plates were also held at $37^{\circ} \mathrm{C}$ for 22 to $24 \mathrm{~h}$. The difference in plate counts between the TSA and TSA/R plates was treated as the population of background microorganisms. The colonies of $S$. aureus and background microorganisms were counted and converted to the logarithm of base 10 (recorded as $\log \mathrm{cfu} / \mathrm{mL}$ ) and then converted to natural logarithm $(\mathrm{ln} \mathrm{cfu} / \mathrm{mL})$ for data analysis. Two replicates of each growth experiment were conducted for each temperature condition.

\section{Primary and Secondary Models}

For S. aureus, the growth curves showed 3 phases, including lag, exponential growth, and stationary phases. Therefore, the Huang primary growth model (Eq. [1] and [2]) was used to describe the growth curves (Huang, 2010, 2013). In Eq. [1], $y(t), y_{0}$, and $y_{\max }$ are the natural logarithms of the bacterial counts (ln cfu/mL) at time $t$, time 0 , and stationary phase; $\mu_{\max }$ is the specific growth rate $\left(\mathrm{h}^{-1}\right), e$ is the natural number (2.718), and $\lambda$ is the lag phase duration (h) at a temperature. $B(t)$ in Eq. [1] is a transitional function defined by Eq. [2]. The parameter $\alpha(=4)$ is a coefficient used to define the transition from the lag phase to exponential growth phase (Huang, 2008, 2013). With the Huang primary model, the duration of the lag phase $(\lambda)$ was explicitly defined in this model:

$$
y(t)=y_{0}+y_{\max }-\ln \left\{e^{y_{0}}+\left[e^{y_{\max }}-e^{y_{0}}\right] e^{-\mu_{\max } B(t)}\right\}
$$




$$
\text { and } B(t)=t+\frac{1}{\alpha} \ln \frac{1+e^{-\alpha(t-\lambda)}}{1+e^{\alpha \lambda}} \text {. }
$$

For background microorganisms, the growth curves did not show significant lag times. Therefore, a no-lag phase model was used (Eq. [3], Fang et al., 2012, 2013). Each variable in this equation is identical to that in Eq. [1]:

$$
y(t)=y_{0}+y_{\max }-\ln \left\{e^{y_{0}}+\left[e^{y_{\max }}-e^{y_{0}}\right] e^{\left.-\mu_{\max } t\right)}\right\} .
$$

To evaluate the effect of storage temperature on the growth rate $\left(\mu_{\max }\right)$ of $S$. aureus in camel milk, the cardinal temperatures model (Eq. [4], Rosso et al., 1993) was used. This model contains $\mu_{\text {opt }}$, which is the estimated optimum specific growth rate observed at the optimum temperature, $T_{o p t} ; T_{\min }$ and $T_{\max }$ are the estimated minimum and maximum growth temperatures, respectively.

$$
\begin{aligned}
& \mu_{\max }= \\
& \frac{\mu_{\text {opt }}\left(T-T_{\max }\right)\left(T-T_{\min }\right)^{2}}{\left[\left(T_{o p t}-T_{\min }\right)\left(T-T_{o p t}\right)-\left(T_{o p t}-T_{\max }\right)\left(T_{o p t}+T_{\min }-2 T\right)\right]\left(T_{o p t}-T_{\min }\right)} .
\end{aligned}
$$

To evaluate the effect of temperature on the lag phase time of $S$. aureus, an empirical equation was used (Eq. [5], Huang, 2015a,b). In Eq. [5], $\lambda$ is the lag time at each temperature (h); $A$ and $m$ are coefficients to be determined by regression:

$$
\ln (\lambda)=A-m \times \ln \left(\mu_{\max }\right) .
$$

\section{Data Analysis}

One set of growth curves from each storage temperature was selected and compiled for analysis using the one-step kinetic analysis method for isothermal growth curves developed by Huang (2017). Data analysis was performed using the USDA IPMP-Global Fit software package (Huang, 2017). To perform one-step kinetic analysis, the isothermal growth curves collected under different incubation temperatures were analyzed simultaneously with a combination of the primary (Eq. [1] or [3]) and the secondary models (Eq. [4] and [5]). Although natural logs of bacterial counts are needed in Eq. [1] and [3], the USDA IPMP-Global Fit allows direct use of $\log _{10}$ of bacterial counts during data entry. The software performs automatic conversion between $\log _{10}$ and natural logs during data analysis. The bac- terial counts are directly reported as $\log _{10}$ after data analysis is completed.

\section{Model Validation}

Another group of growth curves, not used in the estimation of kinetic parameters, was set aside for validation of the primary and secondary models and the associated kinetic parameters. To validate the accuracy of the models, the kinetic parameters estimated in the previous section were used in the primary and secondary models to calculate the bacterial growth at each temperature. The results were compared with the experimentally observed data point-by-point. The difference between the calculation (prediction) $(\hat{y})$ and the corresponding data point $(y)$, which is the bacterial count in $\log \mathrm{cfu} / \mathrm{mL}$, was designated as the error $(\varepsilon)$ of prediction. The root mean square error (RMSE) was calculated from $\varepsilon$ (Eq. [6]), in which $N$ is the number of observations and $P$ is the number of estimated parameters.

$$
R M S E=\sqrt{\frac{\sum \varepsilon^{2}}{N-P}}
$$

\section{RESULTS AND DISCUSSION}

\section{Estimation of Kinetic Parameters}

The camel milk samples used in the experiments, although pasteurized, were not found to be sterile and contained background microorganisms at approximately 3 to $4 \log \mathrm{cfu} / \mathrm{mL}$. The average initial concentration of $S$. aureus in the inoculated camel milk samples was $2.6 \log \mathrm{cfu} / \mathrm{mL}$. At $8^{\circ} \mathrm{C}$, no growth of $S$. aureus was ob-

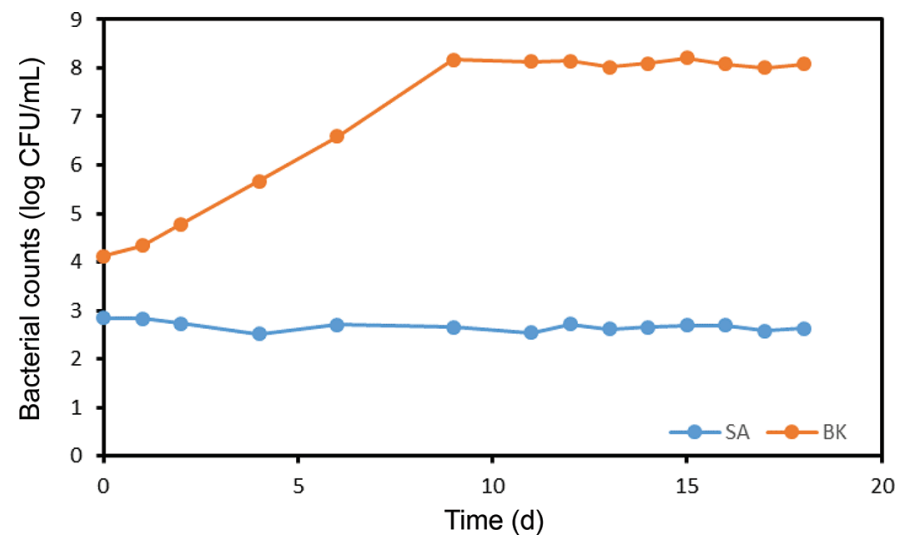

Figure 1. Growth of Staphylococcus aureus (SA) and background microorganisms $(\mathrm{BK})$ in camel milk stored at $8^{\circ} \mathrm{C}$. 
served, whereas the background microorganisms grew well and produced a full growth curve (Figure 1). Between 12 and $43^{\circ} \mathrm{C}$, both $S$. aureus and the background microorganisms grew well in the camel milk samples.

For $S$. aureus, one set of growth curves collected between 12 and $43^{\circ} \mathrm{C}$, including 94 data points, was analyzed with IPMP-Global Fit. Figure 2A shows the comparison between the data and regression curves for S. aureus. Table 1 lists the estimated parameters of the primary and secondary models. For parameter $A$ in Eq. [5], this value was fixed at 0.56 , as this parameter could not be confidently estimated if included in the full model. According to Table 1, the minimum $\left(T_{m i n}\right)$, optimum $\left(T_{o p t}\right)$, and maximum $\left(T_{\max }\right)$ temperatures were estimated as 5.9, 42.0, and $49.2^{\circ} \mathrm{C}$, respectively, for $S$. aureus in camel milk. The estimated maximum cell concentration was $7.1 \log \mathrm{cfu} / \mathrm{mL}$. Because the growth curves showed lag phases, the lag time must be estimated. Figure $3 \mathrm{~A}$ and $3 \mathrm{~B}$ shows the effect of temperature on the specific growth rate $\left(\mu_{\max }\right)$ and lag time $[\log (\lambda)]$, respectively, of $S$. aureus in camel milk. According to the model, the estimated lag time of $S$.

A
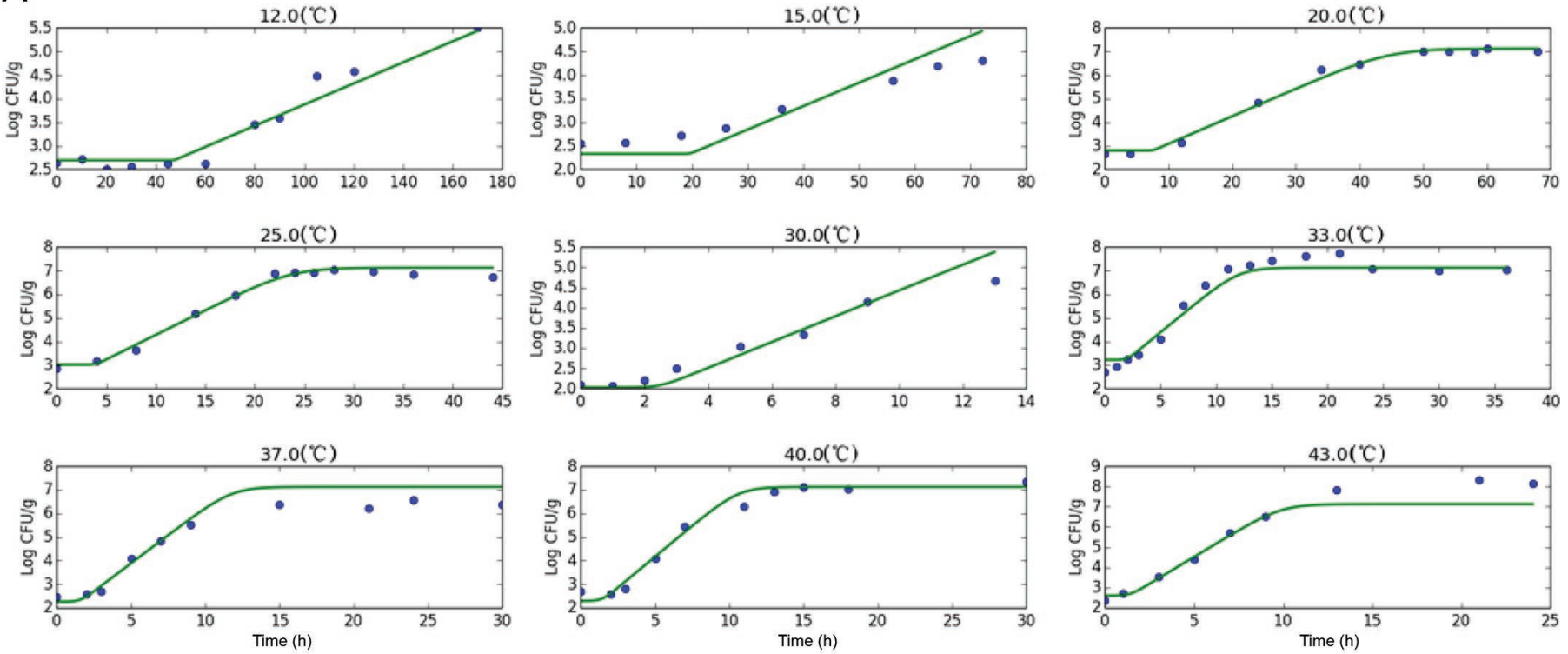

B
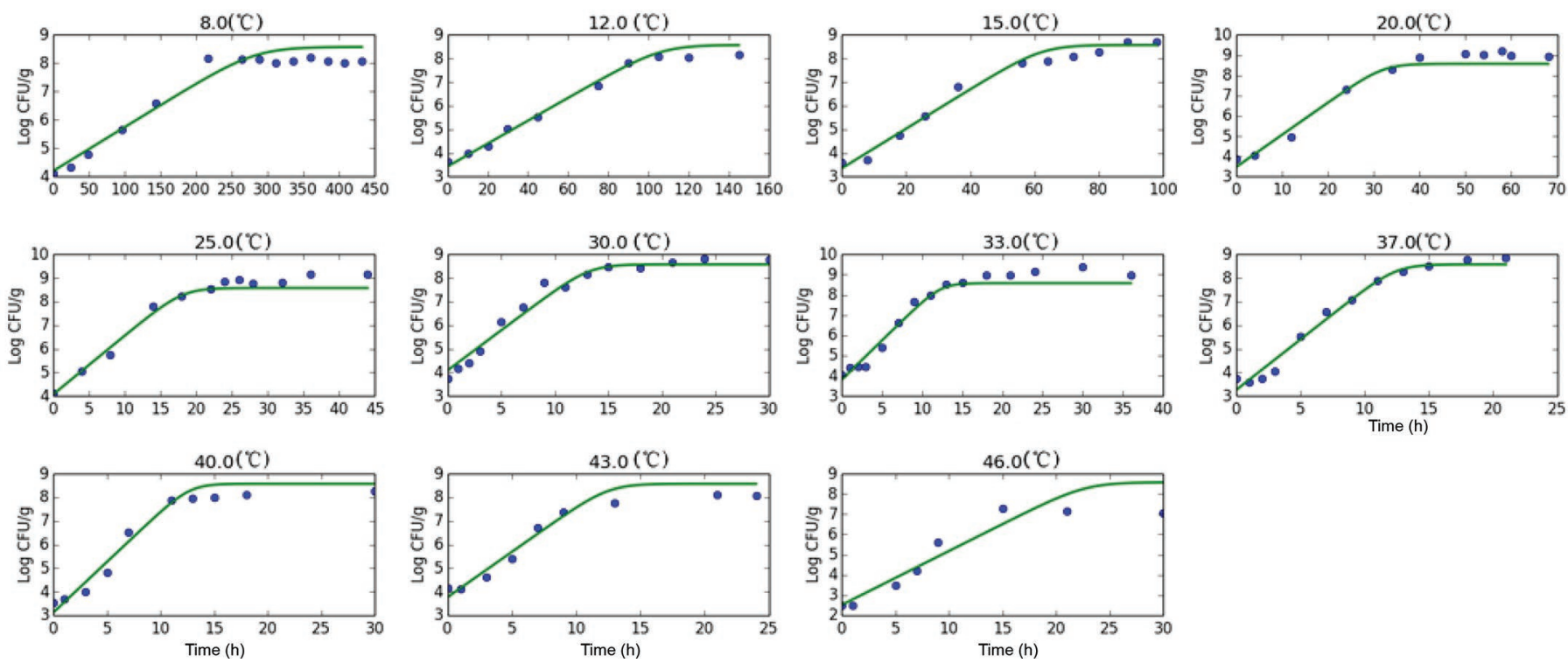

Figure 2. One-step kinetic analysis of growth of (A) Staphylococcus aureus, and (B) background microorganisms in camel milk. 
aureus in camel milk at $8^{\circ} \mathrm{C}$ should be $504 \mathrm{~h}$, or $21 \mathrm{~d}$, which explains why no growth was observed at this temperature (Figure 1).

For background microorganisms, the growth curves from 8 to $46^{\circ} \mathrm{C}$, including 136 data points, were analyzed simultaneously with IPMP-Global Fit. Figure $2 \mathrm{~B}$ shows the results of regression analysis. Table 2 lists the estimated kinetic parameters for background microorganisms. According to Table 2, the estimated $T_{\max }$ of the background microorganisms was the same as that of $S$. aureus, but $T_{\min }$ was about $3^{\circ} \mathrm{C}$, suggesting that background microorganisms can grow in a lower temperature range than $S$. aureus. This is reasonable because the background microorganisms may contain psychrotrophs that can survive better at refrigerated temperatures than $S$. aureus. The optimum growth temperature $\left(T_{\text {opt }}\right)$ occurred at $38.6^{\circ} \mathrm{C}$. Compared with $S$. aureus, the background microorganisms would grow at a slower rate at temperatures above $32^{\circ} \mathrm{C}$ and at a higher rate below this temperature (Figure 3A).

\section{Validation of Models}

According to ICMSF (1996), S. aureus can grow at temperatures between 7 and $48^{\circ} \mathrm{C}$, with an optimum of $37^{\circ} \mathrm{C}$. The growth temperature range for $S$. aureus in camel milk estimated in this study was 5.9 to $49.2^{\circ} \mathrm{C}$. This temperature range agrees well with the range reported in ICMSF (1996), although its optimum temperature was $5^{\circ} \mathrm{C}$ higher. The growth of $S$. aureus was evaluated in sterilized or UHT-treated milk (Fujikawa and Morozumi, 2006; Medvedova et al., 2009) and in cooked potato (Huang, 2015b). The growth rates of $S$. aureus are similar among the studies reported by Fujikawa and Morozumi (2006), Medvedova et al. (2009), and Huang (2015b) in different substrates (Figure 3A). Compared with the specific growth rates reported in these studies, the specific growth rates of both $S$. aureus and background microorganisms in camel milk are apparently lower (Figure 3A), whereas the lag times were apparently longer than those of cow milk reported by Medvedova et al. (2009) within a comparable temperature range (Figure 3B).

Abusheliabi et al. (2017) compared the growth behavior of certain foodborne pathogens, including $S$. aureus, Listeria monocytogenes, Escherichia coli O157:H7, and Salmonella spp., in raw and pasteurized camel milk with that in pasteurized cow milk. That study reported that both raw and pasteurized camel milk exerted bacteriostatic effects against all these pathogens to a certain extent. Benkerroum et al. (2004) reported that camel milk inhibited the growth of $L$. monocytogenes and E. coli O78:K80. An inhibitory effect of camel milk was also reported by Barbour et al. (1984), and the antibacterial activity was attributed to lysozyme in the whey of the camel milk. In addition to lysozyme, other proteins, such as lactoferrin, lactoperoxidase, immunoglobulin G, and secretory immunoglobulin A, may be bacteriostatic against certain gram-positive and gramnegative microorganisms in camel milk (El Agamy et al., 1992). It is apparent that camel milk naturally contains some antimicrobial substances that can suppress the growth of microorganisms at least during the initial stage of incubation or storage, which may explain the slower growth rate and longer lag times found in this study (Figure 3).

Table 1. Estimation of kinetic parameters ${ }^{1}$ for growth of Staphylococcus aureus in camel milk

\begin{tabular}{lcccc}
\hline Variable & Estimate & SE & t value & $P$-value \\
\hline$\mu_{\text {opt }}\left(\mathrm{h}^{-1}\right)$ & 1.24 & 0.22 & 5.55 & $3.66 \times 10^{-6}$ \\
$T_{\text {opt }}\left({ }^{\circ} \mathrm{C}\right)$ & 42.0 & 7.69 & 5.46 & $5.34 \times 10^{-6}$ \\
$T_{\min }\left({ }^{\circ} \mathrm{C}\right)$ & 5.9 & 2.3 & 2.48 & $1.51 \times 10^{-2}$ \\
$T_{\max }\left({ }^{\circ} \mathrm{C}\right)$ & 49.2 & 2.2 & 2.28 & $2.56 \times 10^{-2}$ \\
$\mathrm{~m}$ & 1.11 & 0.367 & 3.03 & $3.93 \times 10^{-3}$ \\
$\mathrm{~A}(\mathrm{fixed})$ & 0.56 & & & \\
$y_{0,12^{\circ} \mathrm{C}}(\log \mathrm{cfu} / \mathrm{mL})$ & 2.7 & 0.4 & 6.33 & $1.38 \times 10^{-8}$ \\
$y_{0,15^{\circ} \mathrm{C}}(\log \mathrm{cfu} / \mathrm{mL})$ & 2.3 & 0.4 & 5.42 & $6.34 \times 10^{-7}$ \\
$y_{0,20^{\circ} \mathrm{C}}(\log \mathrm{cfu} / \mathrm{mL})$ & 2.8 & 0.5 & 5.37 & $7.73 \times 10^{-7}$ \\
$y_{0,25^{\circ} \mathrm{C}}(\log \mathrm{cfu} / \mathrm{mL})$ & 3.0 & 0.5 & 5.82 & $1.22 \times 10^{-7}$ \\
$y_{0,30^{\circ} \mathrm{C}}(\log \mathrm{cfu} / \mathrm{mL})$ & 2.0 & 0.4 & 5.09 & $2.34 \times 10^{-6}$ \\
$y_{0,33^{\circ} \mathrm{C}}(\log \mathrm{cfu} / \mathrm{mL})$ & 3.2 & 0.4 & 7.61 & $5.10 \times 10^{-11}$ \\
$y_{0,37^{\circ} \mathrm{C}}(\log \mathrm{cfu} / \mathrm{mL})$ & 2.7 & 0.5 & 4.17 & $7.70 \times 10^{-5}$ \\
$y_{0,40^{\circ} \mathrm{C}}(\log \mathrm{cfu} / \mathrm{mL})$ & 2.3 & 0.6 & 4.04 & $1.25 \times 10^{-4}$ \\
$y_{0,43^{\circ} \mathrm{C}}(\log \mathrm{cfu} / \mathrm{mL})$ & 2.6 & 0.7 & 4.0 & $1.42 \times 10^{-4}$ \\
$y_{\max }(\log \mathrm{cfu} / \mathrm{mL})$ & 7.1 & 0.2 & 36.4 & $4.41 \times 10^{-51}$ \\
\hline
\end{tabular}

${ }^{1} \mu_{\text {opt }}=$ estimated optimum specific growth rate observed at the optimum temperature; $T_{\text {opt }}=$ optimum temperature; $T_{\min }=$ estimated minimum growth temperature; $T_{\max }=$ estimated maximum growth temperatures; $\mathrm{m}$ and $\mathrm{A}$ are regression coefficients; $y_{0}=\log _{10}$ bacterial counts at time zero at different temperatures; and $y_{\max }$ $=$ natural $\log _{10}$ bacterials count at the stationary phase. The bacterial counts were directly reported as $\log _{10}$ by the software when data analysis was completed. 
A

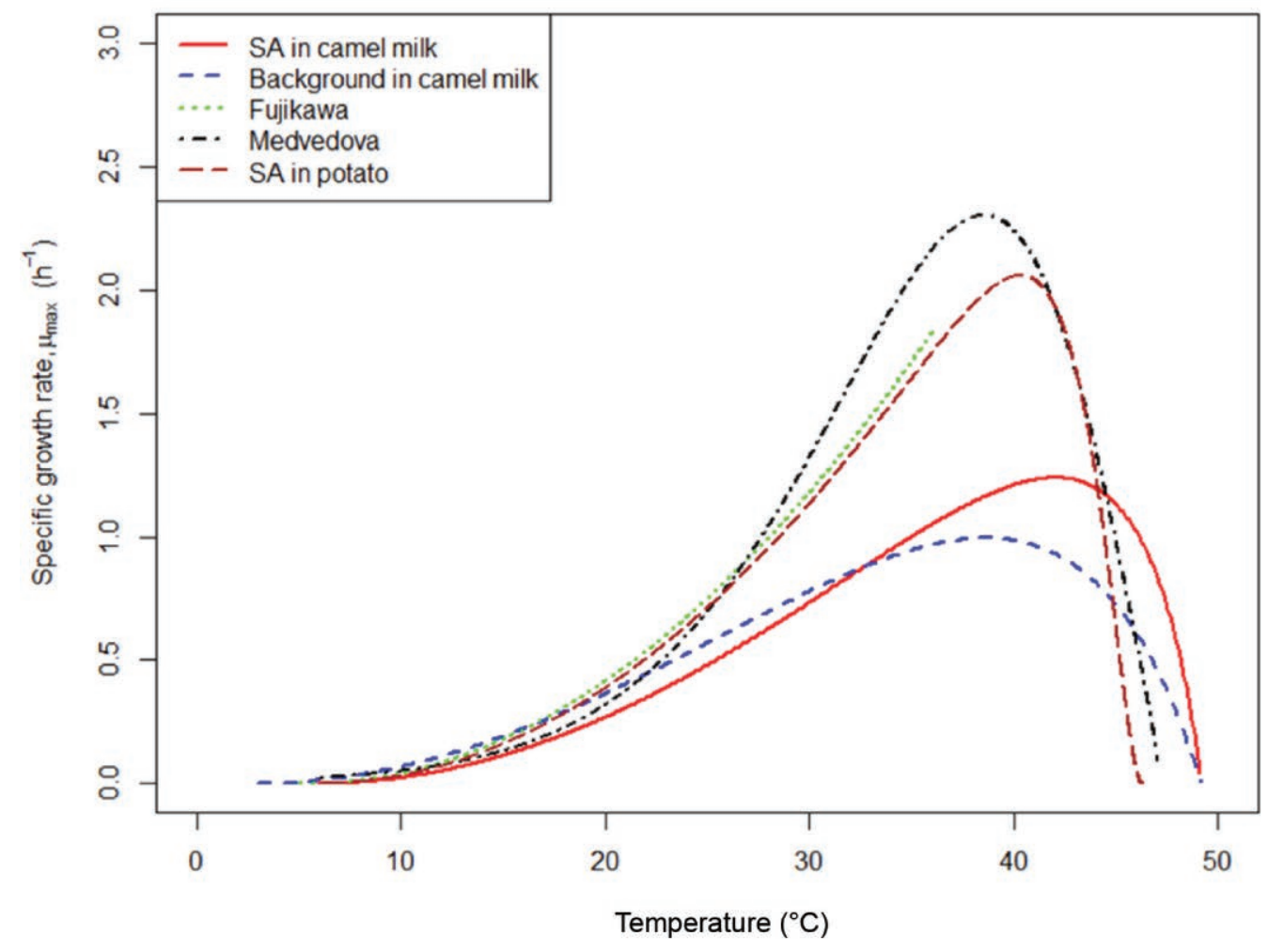

B

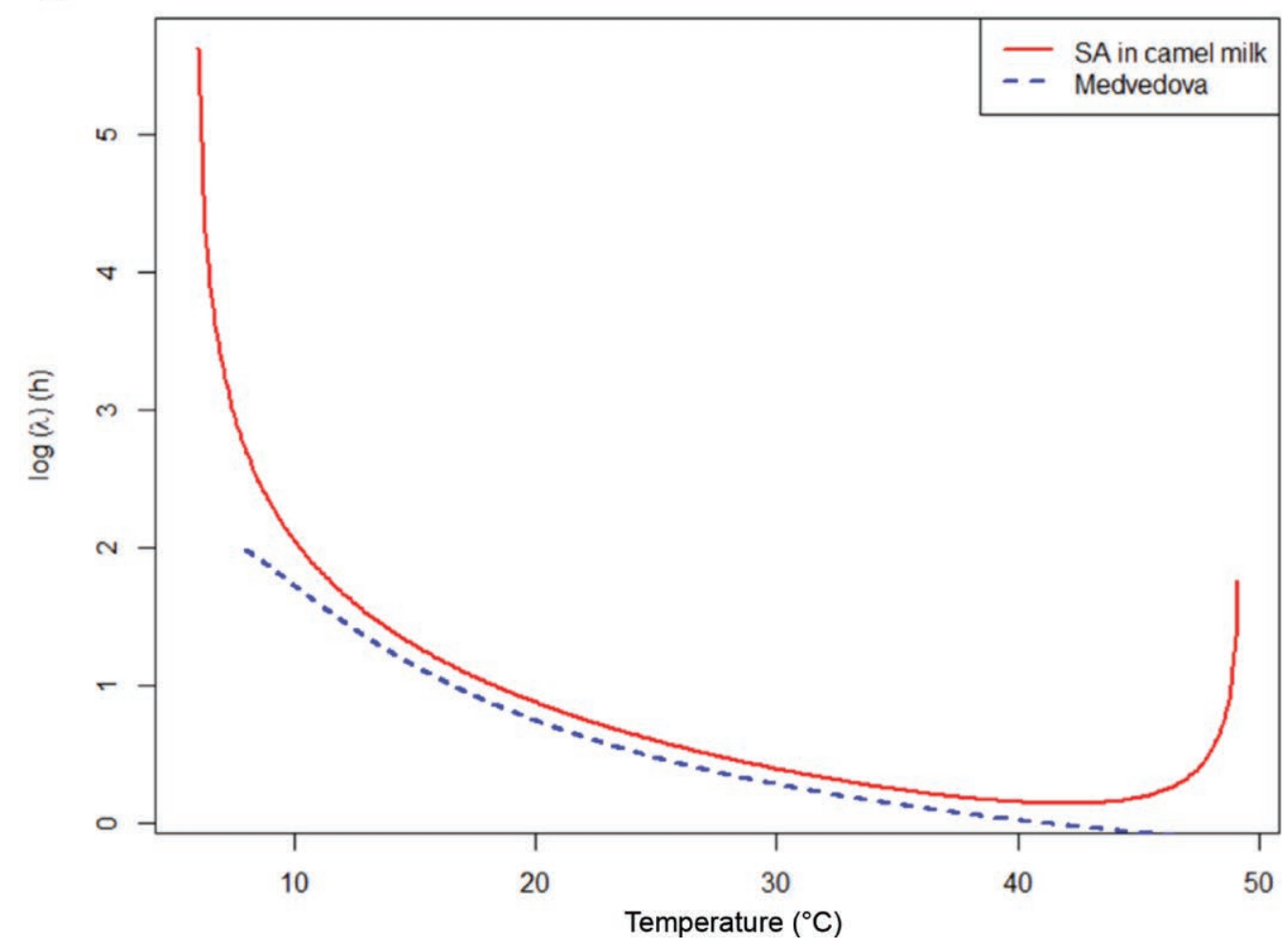

Figure 3. Effect of temperature on (A) specific growth rate and (B) lag times of Staphylococcus aureus (SA) in camel and comparison with data from cow milk and cooked potato. Data sources: SA and background in camel milk = this study; Fujikawa = Fujikawa and Morozumi, 2006; Medvedova = Medvedova et al., 2009; SA in potato $=$ Huang, 2015b. 
Table 2. Estimation of kinetic parameters ${ }^{1}$ for growth of background microorganisms in camel milk

\begin{tabular}{lcccc}
\hline Variable & Estimate & SE & t value & $P$-value \\
\hline$\mu_{\text {opt }}\left(\mathrm{h}^{-1}\right)$ & 0.995 & 0.136 & 7.33 & $4.21 \times 10^{-11}$ \\
$T_{\text {opt }}\left({ }^{\circ} \mathrm{C}\right)$ & 38.6 & 1.8 & 21.3 & $9.78 \times 10^{-41}$ \\
$T_{\min }\left({ }^{\circ} \mathrm{C}\right)$ & 2.97 & 1.39 & 2.14 & $3.48 \times 10^{-2}$ \\
$T_{\max }\left({ }^{\circ} \mathrm{C}\right)$ & 49.2 & 2.7 & 18.2 & $5.72 \times 10^{-35}$ \\
$y_{0,8^{\circ} \mathrm{C}}(\log \mathrm{cfu} / \mathrm{mL})$ & 4.2 & 0.5 & 7.29 & $4.97 \times 10^{-11}$ \\
$y_{0,12^{\circ} \mathrm{C}}(\log \mathrm{cfu} / \mathrm{mL})$ & 3.4 & 0.5 & 7.53 & $1.51 \times 10^{-11}$ \\
$y_{0,15^{\circ} \mathrm{C}(\log \mathrm{cfu} / \mathrm{mL})}$ & 3.4 & 0.5 & 6.76 & $7.02 \times 10^{-10}$ \\
$y_{0,20^{\circ} \mathrm{C}(\log \mathrm{cfu} / \mathrm{mL})}$ & 3.5 & 0.6 & 6.27 & $7.33 \times 10^{-9}$ \\
$y_{0,25^{\circ} \mathrm{C}}(\log \mathrm{cfu} / \mathrm{mL})$ & 4.1 & 0.5 & 7.49 & $1.80 \times 10^{-11}$ \\
$y_{0,30^{\circ} \mathrm{C}}(\log \mathrm{cfu} / \mathrm{mL})$ & 4.1 & 0.4 & 10.2 & $1.15 \times 10^{-17}$ \\
$y_{0,33^{\circ} \mathrm{C}}(\log \mathrm{cfu} / \mathrm{mL})$ & 3.8 & 0.4 & 9.33 & $1.35 \times 10^{-15}$ \\
$y_{0,37^{\circ} \mathrm{C}(\log \mathrm{cfu} / \mathrm{mL})}$ & 3.3 & 0.4 & 7.49 & $1.83 \times 10^{-11}$ \\
$y_{0,40^{\circ} \mathrm{C}}(\log \mathrm{cfu} / \mathrm{mL})$ & 3.1 & 0.5 & 6.26 & $7.68 \times 10^{-9}$ \\
$y_{0,43^{\circ} \mathrm{C}}(\log \mathrm{cfu} / \mathrm{mL})$ & 3.8 & 0.5 & 7.77 & $4.37 \times 10^{-12}$ \\
$y_{0,46^{\circ} \mathrm{C}}(\log \mathrm{cfu} / \mathrm{mL})$ & 2.5 & 0.6 & 4.23 & $4.93 \times 10^{-5}$ \\
$y_{\max }(\log \mathrm{cfu} / \mathrm{mL})$ & 8.6 & 0.2 & 56.3 & $6.74 \times 10^{-83}$ \\
\hline
\end{tabular}

${ }^{1} \mu_{\text {opt }}=$ estimated optimum specific growth rate observed at the optimum temperature; $T_{\text {opt }}=$ optimum temperature; $T_{\min }=$ estimated minimum growth temperature; $T_{\max }=$ estimated maximum growth temperatures; $y_{0}=$ $\log _{10}$ bacterial counts at time zero at different temperatures; and $y_{\max }=\log _{10}$ bacterial counts at the stationary phase. The bacterial counts were directly reported as $\log _{10}$ by the software when data analysis was completed.
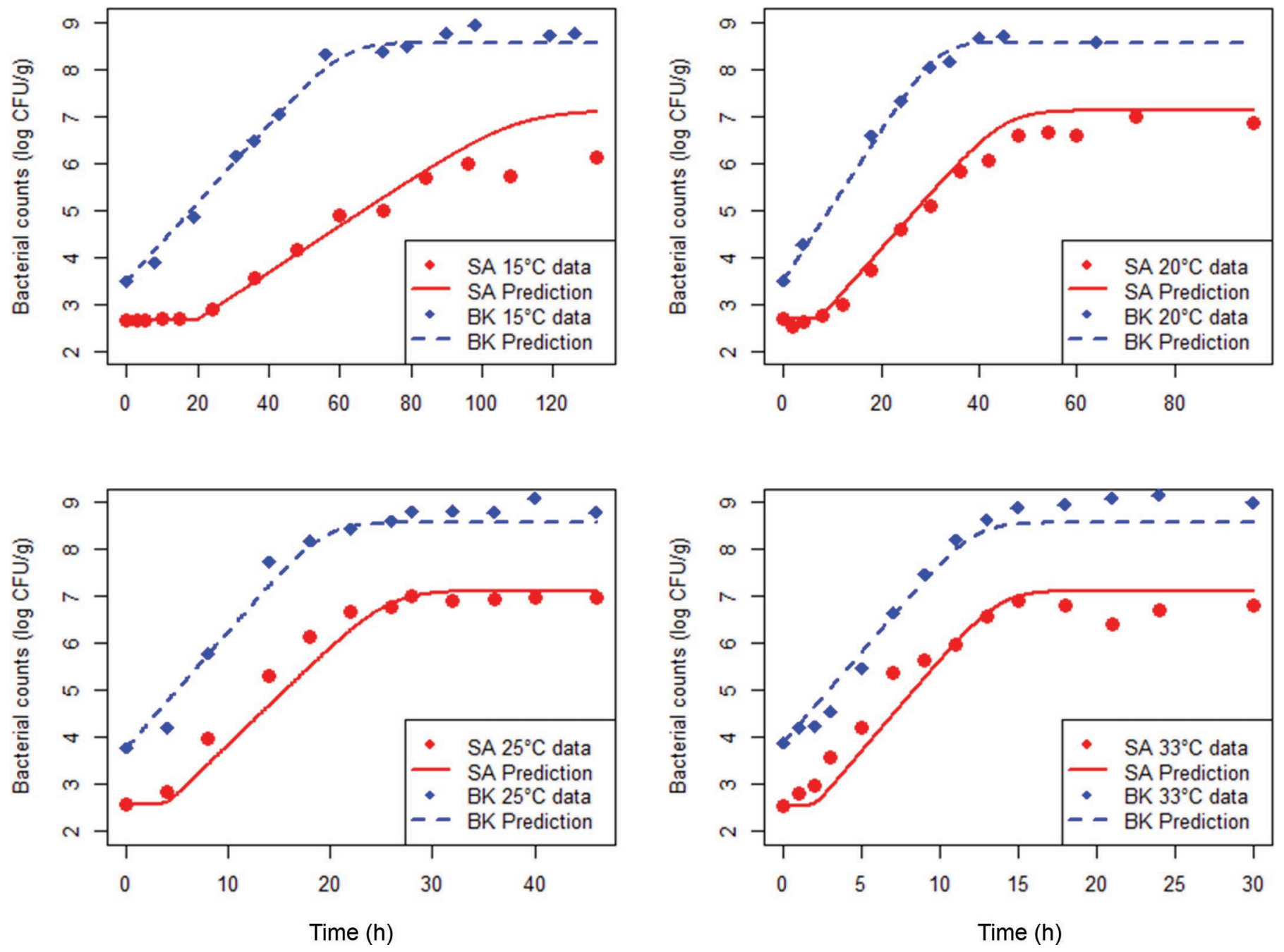

Figure 4. Validation of kinetic parameters and predictive models using growth curves of Staphylococcus aureus (SA) and background microorganisms (BK) observed at $15,20,25$, and $33^{\circ} \mathrm{C}$. 
The kinetic parameters listed in Tables 1 and 2 were used in the primary and secondary models to predict the growth of $S$. aureus and background microorganisms. The predictions were compared with the growth curves (100 data points for $S$. aureus and 106 for the background microorganisms) set aside for validation. Figures 4 and 5 show the comparison between the predictions and the observed growth curves. Figure 6 shows the residual errors $(\hat{y}-y, \log \mathrm{cfu} / \mathrm{mL})$ of prediction for the growth of $S$. aureus and background microorganisms in camel milk. For both $S$. aureus and background microorganisms, the RMSE of predictions was $0.5 \log \mathrm{cfu} / \mathrm{mL}$. The RMSE of prediction was almost the same as those of data analysis.

\section{CONCLUSIONS}

This study investigated the growth of $S$. aureus in camel milk at temperatures ranging from 8 to $43^{\circ} \mathrm{C}$ and compared its growth kinetics with that of background microorganisms. We confirmed that camel milk may have certain antimicrobial properties that inhibit the growth of some microorganisms, such as $S$. aureus. As such, slower growth rates and longer lag times were observed. The growth of $S$. aureus exhibited lag phases, whereas negligible or no lag phases were observed for background microorganisms. One-step kinetic analysis was used to construct mathematical models and estimate the kinetic parameters of $S$. aureus and background microorganisms in camel milk. The estimated $T_{\min }, T_{o p t}$, and $T_{\max }$ were $5.9,42.0$, and $49.2^{\circ} \mathrm{C}$ for $S$. aureus, and $3,38.6$, and $49.2^{\circ} \mathrm{C}$ for the background microorganisms. The $\mu_{\text {opt }}$ was $1.24 \mathrm{~h}^{-1}$ for $S$. aureus and $0.995 \mathrm{~h}^{-1}$ for the background microorganisms. The kinetic parameters and growth models were validated using the data points set aside for validation. The RSME of validation was $0.5 \log \mathrm{cfu} / \mathrm{mL}$ for both $S$. aureus and background microorganisms, suggesting that the growth models are reasonably accurate for predicting growth. The information generated in this study could be used by the food industry and regulatory bodies to predict the growth of $S$. aureus in contaminated camel milk and in risk assessments. They can also be used to predict the general microbiological shelf life of camel milk.

\section{ACKNOWLEDGMENTS}

This work was financially supported by the National Natural Science Foundation of China (NSFC 31601393, 31401597), National and Science Foundation of Fujian Province (2018J01696), Fujian Agricultural and Forestry University (KXb16012A), and Fujian Education
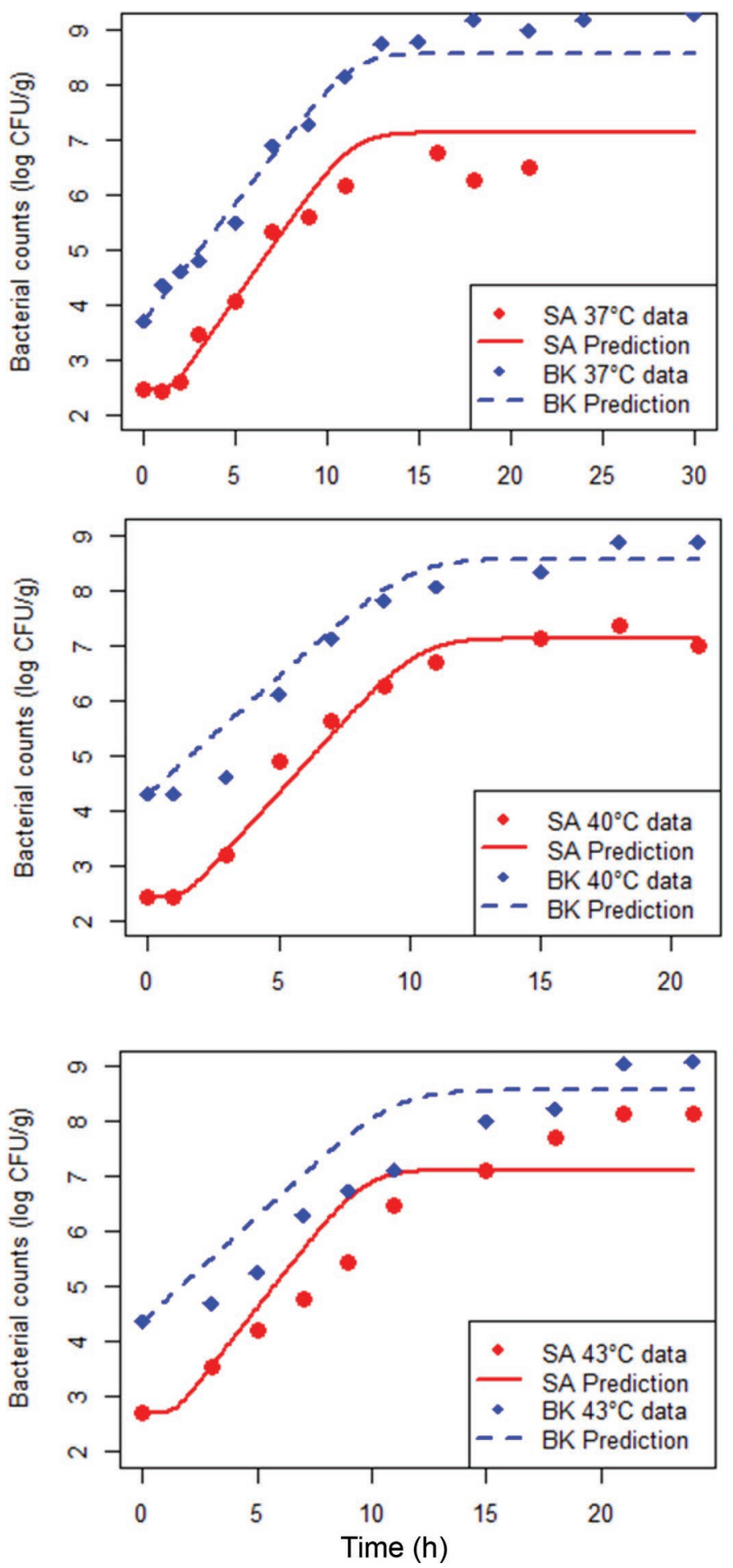

Figure 5. Validation of kinetic parameters and predictive models using growth curves of Staphylococcus aureus (SA) and background microorganisms (BK) observed at 37,40 , and $43^{\circ} \mathrm{C}$.

Department (JAT160147), the 13th five-year plan on Fuzhou Marine Economic Innovation and Development Demonstration City Project. Mention of trade names 


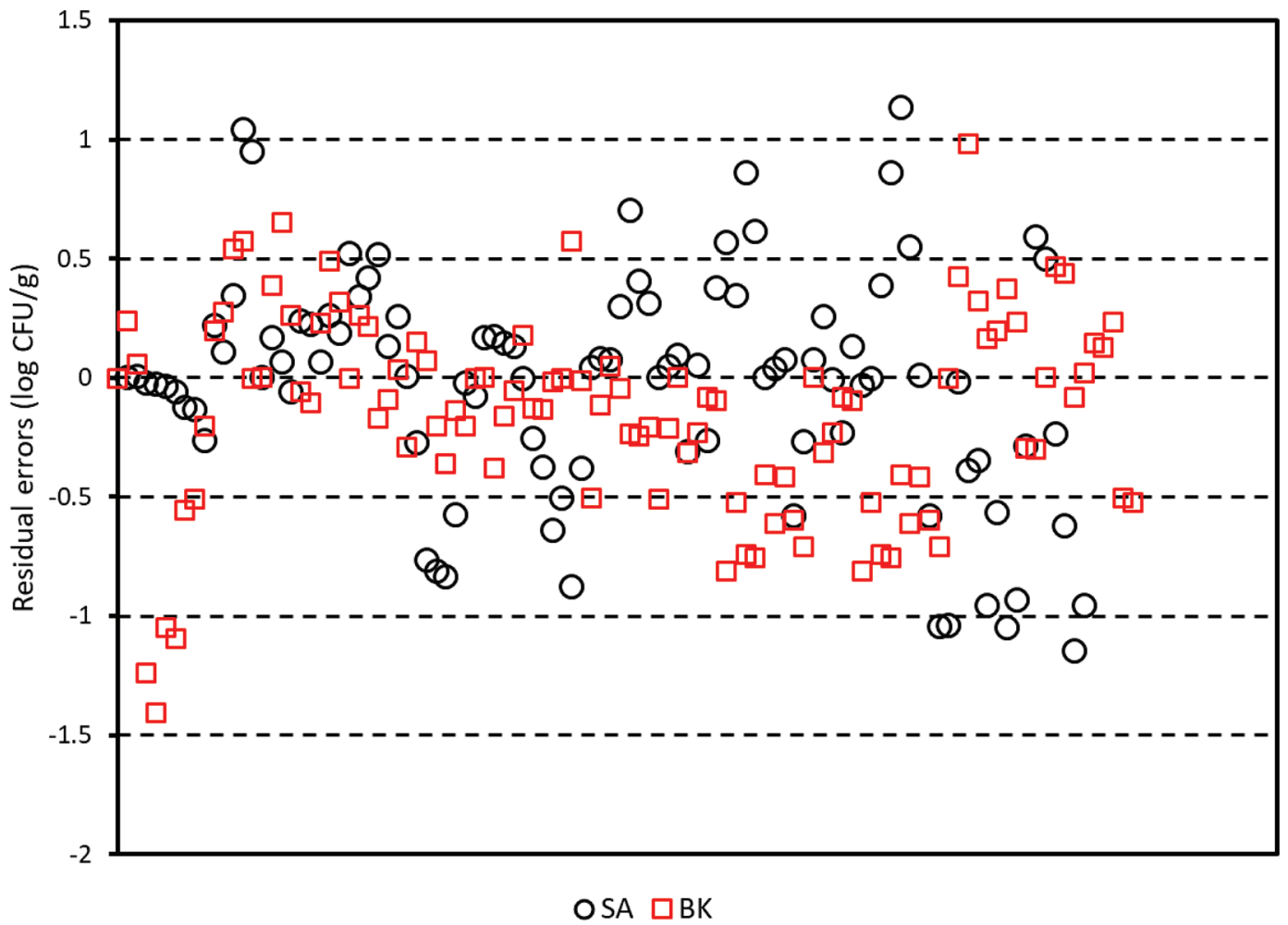

Figure 6. Distribution of residual errors of prediction. SA: Staphylococcus aureus; BK: background microorganisms.

or commercial products in this publication is solely for the purpose of providing specific information and does not imply recommendation or endorsement by the US Department of Agriculture. USDA is an equal opportunity employer and provider. The authors do not have any conflicts of interest.

\section{REFERENCES}

Abera, T., Y. Legesse, B. Mummed, and B. Urga. 2016. Bacteriological quality of raw camel milk along the market value chain in Fafen zone, Ethiopian Somali regional state. BMC Res Notes 9:285. https://doi.org/10.1186/s13104-016-2088-1.

Abusheliabi, A., M. A. Al-Holy, H. Al-Rumaithi, S. Al-Kualdi, A. A. Al-Nabulsi, R. A. Holley, and M. Ayyash. 2017. Growth inhibition of foodborne pathogens in camel milk: Staphylococcus aureus, Listeria monocytogenes, Salmonella spp. and E. coli O157:H7. Czech J. Food Sci. 35:311-320. https://doi.org/10.17221/84/2017-CJFS.

Argudín, M. Á., M. C. Mendoza, and M. R. Rodicio. 2010. Food poisoning and Staphylococcus aureus enterotoxins. Toxins (Basel) 2:1751-1773. https://doi.org/10.3390/toxins2071751.

Asao, T., Y. Kumeda, T. Kawai, T. Shibata, H. Oda, K. Haruki, H. Nakazawa, and S. Kozaki. 2003. An extensive outbreak of staphylococcal food poisoning due to low-fat milk in Japan: Estimation of enterotoxin a in the incriminated milk and powdered skim milk. Epidemiol. Infect. 130:33-40. https://doi.org/10.1017/ S0950268802007951.

Barbour, E. K., N. H. Nabbut, W. M. Frerichs, and H. M. Al-Nakhli. 1984. Inhibition of pathogenic bacteria by camel's milk: Relation to whey lysozyme and stage of lactation. J. Food Prot. 47:838-840. https://doi.org/10.4315/0362-028X-47.11.838.
Benkerroum, N., M. Mekkaoui, N. Bennani, and K. Hidane. 2004. Antimicrobial activity of camel's milk against pathogenic strains of Escherichia coli and Listeria monocytogenes. Int. J. Dairy Technol. 57:39-43. https://doi.org/10.1111/j.1471-0307.2004.00127.x.

Carfora, V., A. Caprioli, N. Marri, D. Sagrafoli, C. Boselli, G. Giacinti, G. Giangolini, L. Sorbara, S. Dottarelli, A. Battisti, and S. Amatiste. 2015. Enterotoxin genes, enterotoxin production, and methicillin resistance in Staphylococcus aureus, isolated from milk and dairy products in central Italy. Int. Dairy J. 42:12-15. https:/ /doi.org/10.1016/j.idairyj.2014.10.009.

CDC (Centers for Disease Control and Prevention). 2016.Surveillance for foodborne disease outbreaks, United States, 2016, Annual Report. CDC, Atlanta, Georgia. US Department of Health and Human Services, CDC, 2018.

El Agamy, E. I., R. Ruppanner, A. Ismail, C. P. Champagne, and R. Assaf. 1992. Antibacterial and antiviral activity of camel milk protective proteins. J. Dairy Res. 59:169-175. https://doi.org/10 $.1017 /$ S0022029900030417.

El-Ziney, M. G., and A. I. Al-Turki. 2007. Microbiological quality and safety assessment of camel milk in Saudi Arabia (Quassim region). Appl. Ecol. Environ. Res. 5:115-122. https://doi.org/10.15666/ aeer/0502_115122.

Elhosseny, M., M. Gwida, M. Elsherbini, M. B. Samra, and M. A. Ashmawy. 2018. Evaluation of physicochemical properties and microbiological quality of camel milk from Egypt. J. Dairy Vet. Anim. Res. 7:92-97.

Fang, T., J. B. Gurtler, and L. Huang. 2012. Growth kinetics and model comparison of Cronobacter sakazakii in reconstituted powdered infant formula. J. Food Sci. 77:E247-E255. https://doi.org/ 10.1111/j.1750-3841.2012.02873.x.

Fang, T., Y. Liu, and L. Huang. 2013. Growth kinetics of Listeria monocytogenes and spoilage microorganisms in fresh-cut cantaloupe. Food Microbiol. 34:174-181. https://doi.org/10.1016/j.fm .2012.12.005. 
FAO (Food and Agriculture Organization). 2020. Livestock primary/ Regions/World + total. Corporate Statistical Database (FAOSTAT). Accessed June 21, 2020. UN Food and Agriculture Organization, Rome, Italy.

Fujikawa, H. 2010. Development of a new logistic model for microbial growth in foods. Biocontrol Sci. 15:75-80. https://doi.org/10 $.4265 /$ bio. 15.75 .

Fujikawa, H., and S. Morozumi. 2006. Modeling Staphylococcus aureus growth and enterotoxin production in milk. Food Microbiol. 23:260-267. https://doi.org/10.1016/j.fm.2005.04.005.

Heidinger, J. C., C. K. Winter, and J. S. Cullor. 2009. Quantitative microbial risk assessment for Staphylococcus aureus and Staphylococcus enterotoxin a in raw milk. J. Food Prot. 72:1641-1653. https://doi.org/10.4315/0362-028X-72.8.1641.

Huang, L. 2008. Growth kinetics of Listeria monocytogenes in broth and beef Frankfurters - Determination of lag phase duration and exponential growth rate under isothermal conditions. J. Food Sci. 73:E235-E242. https://doi.org/10.1111/j.1750-3841.2008.00785.x.

Huang, L. 2010. Growth kinetics of Escherichia coli O157:H7 in mechanically-tenderized beef. Int. J. Food Microbiol. 140:40-48. https://doi.org/10.1016/j.ijfoodmicro.2010.02.013.

Huang, L. 2013. Optimization of a new mathematical model for bacterial growth. Food Control 32:283-288. https://doi.org/10.1016/j foodcont.2012.11.019.

Huang, L. 2015a. Direct construction of predictive models for describing growth of Salmonella Enteritidis in liquid eggs -A onestep approach. Food Control 57:76-81. https://doi.org/10.1016/j .foodcont.2015.03.051.

Huang. L. 2015b. Growth of Staphylococcus aureus in cooked potato and potato salad-A one-step kinetic analysis. J. Food Sci. 80:M2837-M2844. https://doi.org/10.1111/1750-3841.13110.

Huang, L. 2017. IPMP Global Fit-A one-step direct data analysis tool for predictive microbiology. Int. J. Food Microbiol. 262:38-48. https://doi.org/10.1016/j.ijfoodmicro.2017.09.010.

Ibrahim, A. H., and S. A. Khalifa. 2015. Effect of freeze-drying on camel's milk nutritional properties. Int. Food Res. J. 22:1438-1445.

ICMSF. 1996. Staphylococcus aureus. Pages 299-333 (Ch 17) in Microorganisms in Food 5: Microbiological specifications of food pathogens. Blackie Academic and Professional, London, UK.

Ismaili, M. A., B. Saidi, M. Zahar, A. Hamama, and R. Ezzaier. 2019. Composition and microbial quality of raw camel milk produced in Morocco. J. Saudi Soc. Agric. Sci. 18:17-21. https://doi.org/10 .1016/j.jssas.2016.12.001

Kérouanton, A., J. A. Hennekinne, C. Letertre, L. Petit, O. Chesneau, A. Brisabois, and M. L. De Buyser. 2007. Characterization of Staphylococcus aureus strains associated with food poisoning outbreaks in France. Int. J. Food Microbiol. 115:369-375. https://doi .org/10.1016/j.ijfoodmicro.2006.10.050.

Khalesi, M., M. Salami, M. Moslehishad, J. Winterburn, and A. A. Moosavi-Movahedi. 2017. Biomolecular content of camel milk: A traditional super food towards future health care industry. Trends Food Sci. Technol. 62:49-58. https://doi.org/10.1016/j.tifs.2017.02 .004 .

LeLoir, Y., F. Baron, and M. Gautier. 2003. Staphylococcus aureus and food poisoning. Genet. Mol. Res. 2:63-76.

Lee, H., K. Kim, K. H. Choi, and Y. Yoon. 2015. Quantitative microbial risk assessment for Staphylococcus aureus in natural and processed cheese in Korea. J. Dairy Sci. 98:5931-5945. https://doi .org/10.3168/jds.2015-9611.

Lee, H., K. Kim, S. Lee, M. Han, and Y. Yoon. 2014. Growth kinetics of Staphylococcus aureus on brie and camembert cheeses. J. Dairy Res. 81:252-256. https://doi.org/10.1017/S0022029914000144.

Medvedova, A., L. Valik, Z. Sirotna, and D. Liptakova. 2009. Growth characteristics of Staphylococcus aureus in milk: A quantitative approach. Czech J. Food Sci. 27:443-433. https://doi.org/10.17221/ 24/2009-C.JFS.

Mohammadi, K., and S. Hanifian. 2015. Growth and enterotoxin production of Staphylococcus aureus in Iranian ultra-filtered white cheese. Int. J. Dairy Technol. 68:111-117. https://doi.org/10 .1111/1471-0307.12158.

O'Brien, M., K. Hunt, S. McSweeney, and K. Jordan. 2009. Occurrence of foodborne pathogens in Irish farmhouse cheese. Food Microbiol. 26:910-914. https://doi.org/10.1016/j.fm.2009.06.009.

Oliver, S. P., K. J. Boor, S. C. Murphy, S. E. Murinda, and T. R. Callaway. 2009. Food safety hazards associated with consumption of raw milk. Foodborne Pathog. Dis. 6:793-806. https://doi.org/10 $.1089 /$ fpd.2009.0302.

Rosso, L., J. R. Lobry, and J. P. Flandrois. 1993. An unexpected correlation between cardinal temperatures of microbial growth highlighted by a new model. J. Theor. Biol. 162:447-463. https://doi .org/10.1006/jtbi.1993.1099.

Sağlam, A. G., M. Şahin, E. Çelik, Ö. Çelebi, D. Akça, and S. Otlu. 2017. The role of staphylococci in subclinical mastitis of cows and lytic phage isolation against to Staphylococcus aureus. Vet. World 10:1481-1485. https://doi.org/10.14202/vetworld.2017.1481-1485.

Schelin, J., N. Wallin-Carlquist, M. T. Cohn, R. Lindqvist, G. C. Barker, and P. Rådström. 2011. The formation of Staphylococcus aureus enterotoxin in food environments and advances in risk assessment. Virulence 2:580-592. https://doi.org/10.4161/viru.2.6 .18122 .

Schubert, J., S. Krakowiak, and J. Bania. 2018. Production of staphylococcal enterotoxins in food. Med. Weter. 74:16-22. https://doi .org/10.21521/mw.5837.

\section{ORCIDS}

Ting Fang @ https://orcid.org/0000-0002-4045-773X 